\title{
高分子量アルキルアミンの化学的および 物理的性質について*
}

\author{
無機合成に対する溶媒抽出法の適用（第 1 報）
}

$\begin{array}{llllll}\text { 芝 } \text { 田 隼 } \text { 次 }^{1} & \text { 坂 本 } \text { 政 昭 }{ }^{2} \\ \text { 中 } & \text { 西 } \text { 郎 }^{3} & \text { 西 村 山 } \text { 治 }^{+}\end{array}$

\section{1. 緒言}

各種工業原料の重要な部分を占めるアルカリ工業の中で, 重炭酸ナトリウムおよび炭酸ナトリウムの製造にはSolvay が 1866 年に工業化したアンモニアソーダ法が主とし て用いられている。アンモニアソーダ法あるいはソルベー 法とよばれるこの製造過程は次式の一連の反応により示さ れる。

$$
\begin{aligned}
& \mathrm{NaCl}+\mathrm{NH}_{3}+\mathrm{H}_{2} \mathrm{O}+\mathrm{CO}_{2} \rightleftarrows \mathrm{NaHCO}_{3}+\mathrm{NH}_{4} \mathrm{Cl} \\
& \text { ( 炭酸化 ) ……...(1) } \\
& \mathrm{CaCO}_{3} \rightleftarrows \mathrm{CaO}+\mathrm{CO}_{2} \quad \text { (石灰炉反応 ) ……... (2) } \\
& 2 \mathrm{NaHCO}_{3} \rightleftarrows \mathrm{Na}_{2} \mathrm{CO}_{3}+\mathrm{CO}_{2}+\mathrm{H}_{2} \mathrm{O} \text { （烺焼） } \cdots \text { (3) } \\
& 2 \mathrm{NH}_{4} \mathrm{Cl}+\mathrm{Ca}(\mathrm{OH})_{2} \rightleftarrows \mathrm{CaCl}_{2}+2 \mathrm{NH}_{3}+2 \mathrm{H}_{2} \mathrm{O} \\
& \text { (アンモニア蒸留 ) ……....(4) }
\end{aligned}
$$

全体としてみれば次式の反応であり，炭酸がスおよびア ソモニアは循環利用される。

$2 \mathrm{NaCl}+\mathrm{CaCO}_{3} \rightleftarrows \mathrm{Na}_{2} \mathrm{CO}_{3}+\mathrm{CaCl}_{2}$

食塩利用率は式(1)の反応平衡によつて決定され，工業的 には70\%程度といわれている。

アンモニアソーダ法は, 重炭酸ナトリウムの溶解度が塩 化ナトリウム母夜に対して極めて低いことを利用した固液 分離法であるが，ここでアンモニアの代わりに，水に不溶 な液体陰イオン交換剂である高分子量アルキルアミンを適 用すると，式(1)は次式のようになる。

$\mathrm{NaCl}+\mathrm{CO}_{2}+\mathrm{H}_{2} \mathrm{O}+\overline{\mathrm{Am}} \rightleftarrows \mathrm{NaHCO}_{3}+\overline{\mathrm{Am} \mathrm{HCl}} \quad \cdots(6)$ ここで, $\overline{\mathrm{Am}}$ および $\overline{\mathrm{AmHCl}}$ は有機相中のアミンおよび アミン塩酸塩を表わす。式(6)は重炭酸ナトリウムの生成に 対する溶媒抽出法の適用を意味しており, 式(6)の反応平衡 は用いるアミンの塩基度によつて決定される。すなわち, 式(6)の反応を右に進めるには, 重炭酸ナトリウムが生成さ れる $\mathrm{pH}$ 条件の下で副生成する塩酸を，十分に抽出し得る 塩基度の高いアミンを選択することが重要である。

第 1 図は溶媒抽出法を利用した重炭酸ナトリウム生成法 のフローシートを示している。これによりプロセスが簡略 化されるとともに, 食塩母液が回収循環されるので食塩利 用率が著しく改善されると考えられる。

* 1978 年 7 月 26 日受理 昭和 53 年日本鉱業会春季大会にて一部発 表

1. 正会員 工博 関西大学講師 工学部化学工学科

2. 関西大学大学院工学研究科修士課程 (現 富士石油)

3. 関西大学大学院工学研究科修士課程 (現 三徳金属工業 (株) 研究 開発課 )

4. 正会員 工博 関西大学教授 工学部化学工学科
一方，第 1 図のフローシートに示されるように，ソルベ 一法が固液分離であるのに対して，このプロセスは固液液 分離であるために液液分離，すなわち，食塩母液とアミン 有機相の相分離性が検討されねばならない。相分離性には 有機相の比重, 粘度, 界面張力等の性質が関係すると考元 られる。

以上のような観点から, 重炭酸ナトリウムの生成に対し て溶媒抽出法を適用するうえで重要と思われるアミンの塩 基度, 比重, 粘度, アミン塩酸塩の分解等のアミンの化学 的および物理的性質について検討した。

\section{2. アミンの塩基度}

水に可溶なアミンの塩基度はアンモニアく第 1 アミンく 第 2 アミン<第 3 アミンの順で強くなるが，溶媒抽出に用 いられるような水に不溶なアミンの塩基度は第 1 アミン> 第 2 アミン>第 3 アミンの順に弱くなることが知られてい $ろ_{0}^{3)^{4)}}$ ここで, アミンの塩基度は酸と反応寸る傾向であり, またそのアミン酸塩の安定度を示すものである。本研究で は対象となる酸は塩酸であるので, アミン塩酸塩の解離定 数を測定し, これによつてアミンの程基度の尺度とした。

アミン塩酸塩の解離は次式で示される。

$\overline{\mathrm{Am} \mathrm{HCl}} \rightleftarrows \overline{\mathrm{Am}}+\mathrm{H}^{+}+\mathrm{Cl}^{-}$

ここで, 次の 3 つ仮定, すなわち水相の活量俰数は 1 , 有機相中の 2 つの種 $(\overline{\mathrm{Am}}, \overline{\mathrm{Am} \mathrm{HCl}})$ の活量保数の比は 1， $\overline{\mathrm{Am} \mathrm{HCl}}$ は会合しないという仮定を考えると，式(7)の 解離定数 $K_{a}$ は次式で示される。

$K_{a}=[\overline{\mathrm{Am}}]\left[\mathrm{H}^{+}\right]\left[\mathrm{Cl}^{-}\right] /[\overline{\mathrm{AmHCl}}]$

式(8)において $[\overline{\mathrm{Am}}]=[\overline{\mathrm{Am} \mathrm{HCl}}]$ となる点, すなわち 半中和点を求め, さらに $\left[\mathrm{Cl}^{-}\right]=1 \mathrm{~mol} / l$ と一定に維 持すれば式(8)は次式で示される。

$K_{a}=\left[\mathrm{H}^{+}\right]_{1 / 2}, \quad p K_{a}=\mathrm{pH}_{1 / 2}$

ここで, $\left[\mathrm{H}^{+}\right]_{1 / 2}, \mathrm{pH}_{1 / 2}$ はそれぞれ半中和点における水 相の水素イオ擃度および $\mathrm{pH}$ である。したがつて，アミ ン塩酸塩の解離定数は半中和点に扔ける有機相と平衡な水 相の $\mathrm{pH}$ 值から求めることができる。式の誘導の中で用い た仮定については, 水相の組成を一定にし，イオン強度を 一定に保つことにより活量保数は一定となり, $p K_{a}$ 值 に よりアミンの塩基度を比較検討するには十分であると思わ れる。アミン塩酸塩の会合については, その濃度が高い場 合には会合の影響が大きく式(9)を適用できないが，アミン 塩酸塩濃度が $0.1 \mathrm{~mol} / l$ 程度では会合による影響は少ない 


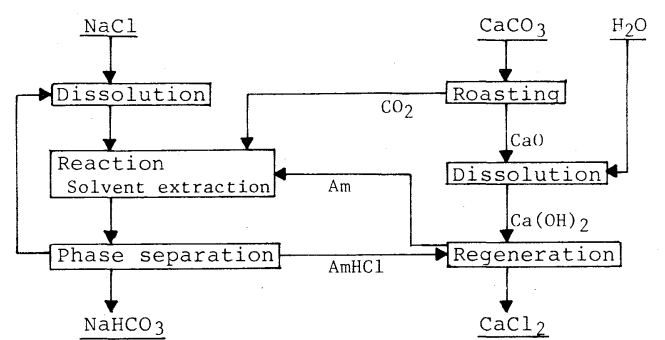

Fig. 1 Schematic flowsheet.
Table 1 Formula and properties of amines.

\begin{tabular}{l|c|c|c|c}
\hline \multicolumn{1}{c|}{ Amine } & Formula & $\begin{array}{l}\text { Molecular } \\
\text { weight }\end{array}$ & $\begin{array}{l}\text { Specific } \\
\text { gravity } \\
\text { at } 25^{\circ} \mathrm{C}\end{array}$ & $\begin{array}{l}\text { Kinetic } \\
\text { viscosity } \\
\text { at 25 } \\
\text { [C.s. } \mathrm{C}\end{array}$ \\
\hline Priment JMT & $\mathrm{RNH}_{2}\left(\mathrm{R}=\mathrm{C}_{18}-\mathrm{C}_{24}\right)$ & 350.8 & 0.849 & 20.1 \\
Amberlite LA-1 & $\mathrm{R}_{2} \mathrm{NH}\left(\mathrm{R}=\mathrm{C}_{10}-\mathrm{C}_{14}\right)$ & 427.5 & 0.854 & 87.2 \\
Amberlite LA-2 & $\mathrm{R}_{2} \mathrm{NH}\left(\mathrm{R}=\mathrm{C}_{10}-\mathrm{C}_{14}\right)$ & 365.4 & 0.826 & 20.3 \\
Farmin T08 & $\mathrm{R}_{3} \mathrm{~N}\left(\mathrm{R}=\mathrm{C}_{8}-\mathrm{C}_{10}\right)$ & 378.4 & 0.809 & 9.8 \\
Alamine 310 & $\mathrm{R}_{3} \mathrm{~N}\left(\mathrm{R}=\mathrm{C}_{8}-\mathrm{C}_{10}\right)$ & 445.3 & 0.825 & 30.4 \\
Alamine 336 & $\mathrm{R}_{3} \mathrm{~N}\left(\mathrm{R}=\mathrm{C}_{8}-\mathrm{C}_{10}\right)$ & 422.0 & 0.814 & 12.8 \\
T.O.A. & $\mathrm{R}_{3} \mathrm{~N}\left(\mathrm{R}=\mathrm{C}_{8}-\mathrm{C}_{10}\right)$ & 353.7 & 0.808 & 9.7 \\
\hline
\end{tabular}

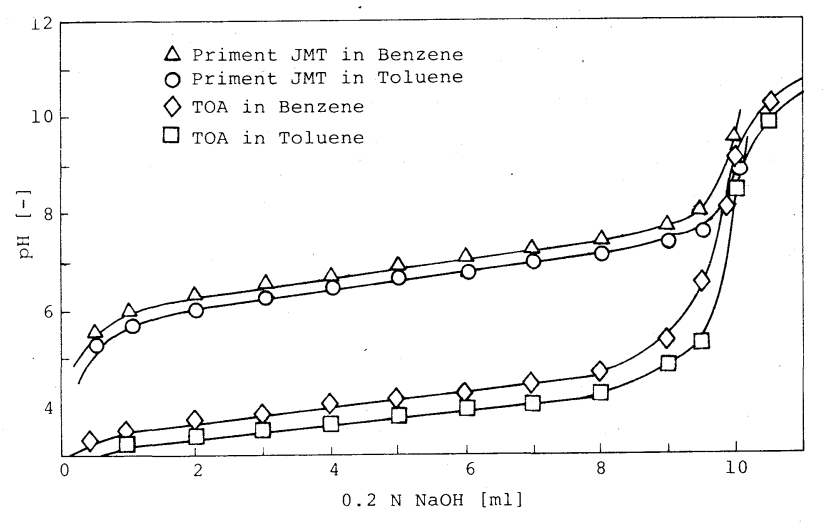

Fig. 2 Titration curves of amine hydrochlorides. Organic phase; $0.1 \mathrm{M} / 1$ amine in diluents. Aqueous phase; $1.0 \mathrm{M} / 1 \mathrm{NaCl}$.

Titrant; $0.2 \mathrm{~N} \mathrm{NaOH}$ in $0.8 \mathrm{M} / 1 \mathrm{NaCl}$.

と思われる。

\section{$2 \cdot 1$ 試薬および実験方法}

実験に供したアミンは第 1 アミンであるPrimentJ MT， 第 2 アミジでるAmberl i te LA - 1, LA-2 (Rohm \& Haas 社製)，第 3 アミンである Farmin T 08(花王石醶(株)， Alamine 310, 336 (General Mills, 社製), T O A (和光純薬製) であり，それらの構造および性質は第 1 表 に示されている。希釈剤にはn-Butyl alcohol,i-Amyl alcohol, Benzene, Tolueneを用い, これらの希釈剂に 溶解したアミンの塩基度を測定した。

各アミンを各希釈剂に溶解し, その濃度を $0.1 \mathrm{~mol} / l$ と する。この有機相をアミンと当量の程酸水溶液と分液口ト中で振盪接触することにより $0.1 \mathrm{~mol} / l$ アミン塩酸塩を 作成する。生成した $0.1 \mathrm{~mol} / l$ アミン塩酸塩 $20 \mathrm{~m} l$ と 1.0 $\mathrm{mol} / l \mathrm{NaCl}$ 溶液 $50 \mathrm{~m} l$ をビーカーに採取し, $0.2 \mathrm{~mol} / l$ $\mathrm{NaOH}+0.8 \mathrm{~mol} / l \mathrm{NaCl}$ 混合溶液で滴定し, 平衡になつ た時の水相の $\mathrm{pH}$ を測定し, 滴定曲線を描く。この滴定曲 線から半中和点での $\mathrm{pH}$ 值を読みとり，アミン塩酸塩の $p K_{a}$ 值が求められる。上記の操作により, 水相中のイオン 強度および塩素イオン濃度は一定に保たれる。滴定には平 沼産業製自動滴定記録装置RAT-11Sを用いた。

\section{$2 \cdot 2$ 実験結果および考察}

第 2 図はPriment JMTおよびTOA の塩基度を求める ために測定した滴定曲線の例である。先に述べたように， これらの滴定曲線の半中和 $\mathrm{pH}\left(\mathrm{p} \mathrm{H}_{1 / 2}\right)$ を読みとることに よりアミン塩酸塩の解離定数 $p K_{a}$ が求められる。測定の結 果は第 2 表に示されている。表には希釈剤の比誘電率が同
Table 2 Apparent dissociation constants of amine hydrochlorides.

\begin{tabular}{l|c|c|c|c|c}
\hline Diluents & $\begin{array}{l}\text { n-Butyl } \\
\text { alcohol }\end{array}$ & $\begin{array}{l}\text { i-Amyl } \\
\text { alcohol }\end{array}$ & Benzene & Toluene \\
\hline \multirow{6}{*}{ pK $_{\mathrm{a}}$ ariment JMT } & 8.35 & 7.85 & 6.90 & 6.70 \\
& Amberlite LA-1 & 7.25 & 6.75 & 4.71 & 4.66 \\
Amberlite LA-2 & 7.85 & 7.46 & 5.51 & 5.35 \\
Farmin T08 & 6.95 & 6.71 & 4.08 & 3.76 \\
Alamine 310 & 6.49 & 6.35 & 3.57 & 3.45 \\
Alamine 336 & 6.91 & 6.68 & 4.13 & 3.74 \\
& T.O.A. & 7.06 & 6.90 & 4.10 & 3.75 \\
\hline Dielectric constant & 17.1 & 13.9 & 2.28 & 2.38 \\
\hline
\end{tabular}

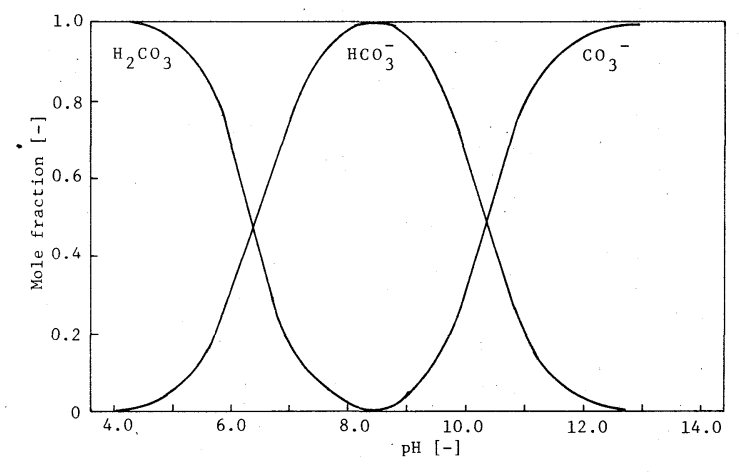

Fig. 3 Distribution of $\mathrm{H}_{2} \mathrm{CO}_{3}$ in aqueous solution calculated from dissociation constants.

時に示されている。 希釈剤の種類にかかわらずPriment $\mathrm{JMT}$ の塩基度が他のアミンの塩基度よりも高く, 第 1 アミ ン>第 2 アミン>第 3 アミンの順にアミンの塩基度は弱く なることが認められる。また，誘電率の高い希釈剤を用い た場合にはアミンの塩基度は高くなることがわかる。これ は, アミンの塩基度がアミン塩酸塩の解離に基ついて測定 されるので, 希釈剤の誘電率によるアミン塩酸塩イオン対 の安定性によつて決定されると考えられる。イオン間に働 くクーロン力 $f$ は次式により与えられる。

$$
f=\frac{1}{4 \pi \varepsilon} \frac{Q_{1} \cdot Q_{2}}{\gamma^{2}}
$$

ここで， $Q_{1} Q_{2}$ はイオン電荷，rはイオン間距離である。 したがつて，1つの溶媒中では溶媒の誘電率が低いほど $f$ は大きく, イオン対は安定である。しかしながら, 誘電率 の異なる 2 つ溶媒間の分配をも考慮するときには，2 溶 媒間の静電的自由エネルギー変化が考えられねばならない。 2 溶媒間の静電的自由エネルギー変化は次式で示される。

$$
\Delta F_{\mathrm{aq} \rightarrow \text { org }}=N_{0}\left(\frac{e^{2}}{2 \gamma_{+}}+\frac{e^{2}}{2 \gamma_{-}}\right)\left(\frac{1}{\varepsilon_{\mathrm{org}}}-\frac{1}{\varepsilon_{\mathrm{aq}}}\right) \cdots \text { (11) }
$$

ここで, $\gamma_{+} \gamma_{-}$は陽イオン, 陰イオンのイオン半径であり, 
$\varepsilon_{\mathrm{org}}, \varepsilon_{\mathrm{aq}}$ は有機溶媒, 水の誘電率である。有機溶媒の誘電 率が低くなると, 自由エネルギー変化 $\Delta F_{\mathrm{aq} \rightarrow \mathrm{org}}$ は大きく なり, 有機溶媒中のイオン対は不安定となる。したがつて, 第 2 表に示されるように希瀵剂の誘電率が高くなるとアミ ンの塩基度は高くなるものと思われる。

次に, 溶媒抽出法を利用した重炭酸ナトリウムの生成反 応式(6)に適切なアミンの塩基度について検討する必要があ る。そのためには, 重炭酸イオン $\mathrm{HCO}_{3}^{-}$が安定に存在し得 る $\mathrm{pH}$ 条件の下で, 塩酸を抽出できる程度のアミンの塩基 度が望まれる。そこで炭酸水溶液中に存在する種のモル分 率を $\mathrm{pH}$ の関数として表わす。炭酸は次式のように 2 段に 解離する。

$$
\left.\begin{array}{ll}
\mathrm{H}_{2} \mathrm{CO}_{3} \rightleftarrows \mathrm{H}^{+}+\mathrm{HCO}_{3}^{-} & \mathrm{K}_{1}=4.2 \times 10^{-7} \\
\mathrm{HCO}_{3} \rightleftarrows \mathrm{H}^{+}+\mathrm{CO}_{3}^{2-} & \mathrm{K}_{2}=4.8 \times 10^{-11}
\end{array}\right\} \cdots(12)
$$

式(12)の炭酸の解離定数を用いて炭酸種のモル分率を計算 すると第 3 図のように表わすことができる。図から明らか なように $\mathrm{pH}$ 值 6.4〜10.3の間では, 重炭酸イオンは他の 種より安定に存在し, $\mathrm{pH}$ 值約 8.3 の時, 最も安定である。 そこで, 水相の $\mathrm{pH}$ が 6.4 以上の状態で塩酸を抽出できる ような塩基度をもつアミンが式(6)による重炭酸ナトリウム の生成に適していると考えられる。すなわち, すくなくと も $p K_{1}(6.4)<\mathrm{pK}_{\mathrm{a}}$ の関係を満たすようなアミンが必要 である。

以上の検討から式(6)による重炭酸ナトリウムの生成には， 第 2 表の 4 種の希釈剂で希釈したPriment JMTおよびア ルコール系希釈剤に希釈したアンが適切であり，上記の 条件を満たすことがわかる。また, 芳香族系希䆏剤で希釈 した第 2 アミン，第 3 アミンでは, 式(6)の反応をほとんど 進めることができないと判断される。一方，アミンの塩基 度の上限はアミン塩酸塩の分解の観点から決定されねばな らない。アミン塩酸塩のアミンへの再生にはアミンの塩基 性よりも高い塩基性をもつ塩基が必要であり, アミンの塩 基性が低いほど有利であることは容易に理解できる。

\section{3. アミンとアミン塩酸塩の動粘度および比重}

液液分離において，その分相性は装置設計上の重要な日 子であり, 分相性の良否は相分離装置の大ささに直接影響 をおよぼす。この分相性は二液相の比重差, 粘度, 界面張 力等と関連し, これら 3 つ性質から評価されることが多 い。ㄴ) 上記の性質の中で, 粘度の増加は相分離を妨げるばか りでなく, 各プロセスを連結する管路において圧力損失の 要因となり, 高粘度の液体は一般に取扱いが容易でなくな る。そこで溶媒抽出法を利用した重炭酸ナトリウムの生成 を行なうための資料とすることを目的として,アミンおよ びアミン塩酸塩の動粘度，比重の測定を行なつた。

\section{$3 \cdot 1$ 試薬および実験方法}

使用した試薬は $2 \cdot 1$ に示したものと同様である。測定 に用いた有機相はアミン希釈剂溶液を濃度既知の塩酸水溶 液と接触させ $25^{\circ} \mathrm{C}$ に保つた恒温水槽に 30 分間静置する ことにより作製した。有機相中のアミン濃度は, 塩酸のメ タノール+ブタノール $(1+1)$ 混合溶液を用いてブロムク
レゾールグリーンを指示薬として中和滴定により決定した。 また,アミン塩酸塩濃度は初期のアミン濃度からアミン塩 酸塩生成後の遊離アミン濃度を差し引くことにより求めた。 粘度測定にはウッベローデ懸垂形粘度計を使用した。

\section{$3 \cdot 2$ 実験結果および考察}

実験に用いたアミンおよび希釈剤の $25^{\circ} \mathrm{C}$ における動粘 度と比重はそれぞれ第 1 表, 第 3 表に示されている。第 3 アミンであるTOA, Farmin T08は動粘度, 比重ともに Priment JMTより低い值をもつことがわかる。第 4 図に は各希釈剤によりアミン濃度を $1.0 \mathrm{~mol} / l$ とした時の有機 相中のアミン程酸程濃度と動粘度の関係が示されている。 図中のアミン程酸塩濃度 0 の点は各希䆏剤により $1.0 \mathrm{~mol}$ $/ l$ としたアミンの動粘度を表わす。アミン単独での動粘 度は前述のようにPriment JMTよりTOAの方が低い值 であつたが，アミン濃度 $1.0 \mathrm{~mol} / l$ は容量百分率では約 $40 \%$ であり, 有機相の粘度はアミン自体より希釈剤によ つて左右され，芳香族系希釈剤で希釈した場合の方がアル コール系希釈剤による場合よりも低粘度である。また，ア ミンの種類にかかわらず,アミンは遊離アミンとして存在す る場合よりもアミン塩酸程を形成した時の方がその動粘度 は高く, TOA の方がアミン塩酸塩になつた時に動粘度の 増加は著しい。第 5 図はベンゼンで希瀵した $0.5 \sim 2.0 \mathrm{~mol}$ $/ l$ のPriment J MT を用いて動粘度と有機相中のアミン 塩酸塩濃度との関係を調べたものである。図中のアミン塩 酸塩濃度 0 の点はそれぞれ $0.5 \sim 2.0 \mathrm{~mol} / l$ Priment JMT の動粘度を示している。アミン濃度 $1.0 \mathrm{~mol} / l$ まで は, アミンがアミン塩酸塩になつた時にその動粘度は直線 的にわずかに増加するが，アミン濃度が $1.0 \mathrm{~mol} / l$ をこ えると, そのアミン塩酸塩の動粘度は指数関数的に著しく 増加する。第 6 図は, ベンゼンで希釈した $2.0 \mathrm{~mol} / l$ の Priment JMTおよび $1.5 \mathrm{~mol} / l$ のT OA を用いて, そ れぞれ有機相の比重とアミン塩酸塩濃度との関係を調べた ものである。図中のアミン塩酸塩濃度 0 の点は $2.0 \mathrm{~mol} / l$ Priment JMTおよび $1.5 \mathrm{~mol} / l$ TOA の比重を示して いる。アミン塩酸塩濃度の増加 (転化の増加) に伴つて比 重が直線的に増大している。したがつて, アミン塩酸塩濃 度が増加するにつれて水相と有機相の比重差は小さくなり, 分相性を悪くすると思われる。

したがつて, 重炭酸ナトリウム生成に対する溶媒抽出法 の適用を考える時, アミンおよびアミン塩酸塩の動粘度, 比重の点から,アルコール系希釈剤や, T OA の使用は好 ましくなく，またアミン濃度についてもせいせい $1.5 \mathrm{~mol}$ $/ l$ 程度までにとどめるべきであると考えられる。

\section{4. アミン塩酸塩の遊離アミンへの分解について}

アミン塩酸塩の遊離アミンへの分解再生については，ア ミンの塩基性と関連があり, 塩基性の強いアミンほど, そ のアミン塩酸塩の分解再生は困難となる。アミン塩酸塩か ら塩酸を除き, 遊離アミンに再生するにはアミンの塩基性 よりも強い塩基性をもつ塩基を必要とする。そこで再生に 用いる塩基として, 水酸化カルシウムおよびアンモニア水 
Table 3 Kinetic viscosity and specific gravity of solvent at $25^{\circ} \mathrm{C}$

\begin{tabular}{l|c|c}
\hline Solvent & Kin.Visc.[c.s.] & Sp.Gr. \\
\hline n-BuOH & 3.18 & 0.807 \\
i-AmOH & 4.72 & 0.806 \\
Benzene & 0.720 & 0.890 \\
Toluene & 0.672 & 0.864 \\
\hline
\end{tabular}

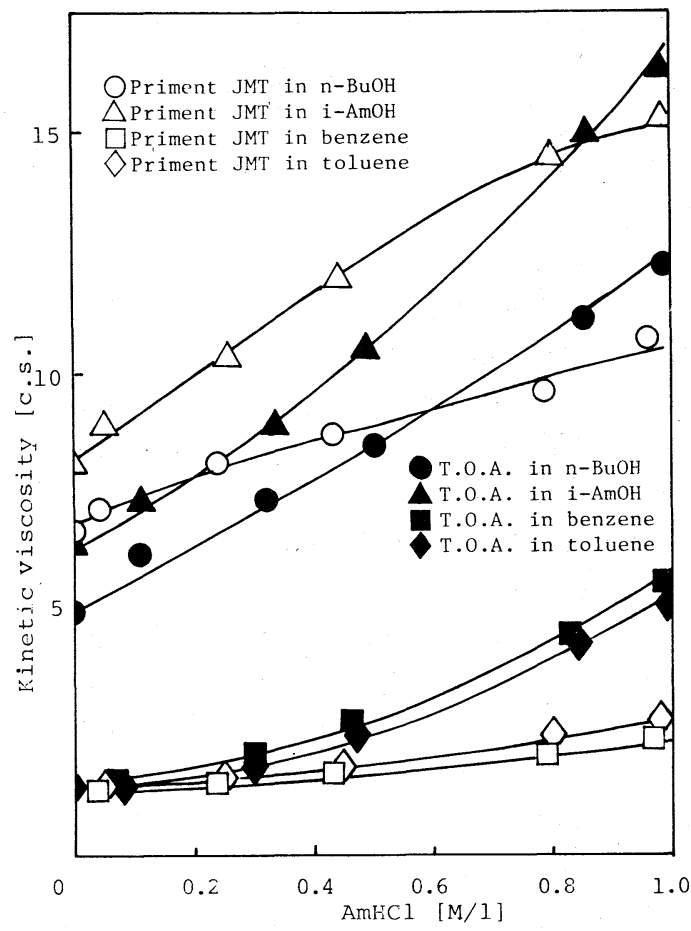

Fig. 4

Relationship between concentration of amine hydrochloride and kinetic viscosity.

Organic phase;

1.0 $\mathrm{M} / 1$ Amine in diluents.

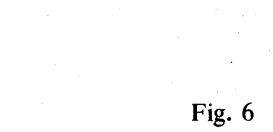

Relationship between concentration of amine hydrochloride and specific gravity at $25^{\circ} \mathrm{C}$ Organic phase; Priment JMT in benzene, TOA in benzene.

を用いてアミン塩酸塩の剥離再生性について検討した。ア ミン塩酸塩の分解再生に関寸る反応式は次のようである。

$2 \overline{\mathrm{AmHCl}}+\mathrm{Ca}(\mathrm{OH})_{2} \rightleftarrows \mathrm{CaCl}_{2}+2 \overline{\mathrm{Am}}+2 \mathrm{H}_{2} \mathrm{O}$

$\overline{\mathrm{Am} \mathrm{HCl}}+\mathrm{NH}_{4} \mathrm{OH} \rightleftarrows \mathrm{NH}_{4} \mathrm{Cl}+\overline{\mathrm{Am}}+\mathrm{H}_{2} \mathrm{O}$

$\left.2 \mathrm{NH}_{4} \mathrm{Cl}+\mathrm{Ca}(\mathrm{OH})_{2} \rightleftarrows \mathrm{CaCl}_{2}+2 \mathrm{NH}_{3}+2 \mathrm{H}_{2} \mathrm{O}\right\}$

\section{$4 \cdot 1$ 試薬および実験方法}

用いた試薬は前節と同様である。有機相中のアミンと当 量の塩酸水溶液とを接触し, アミン塩酸塩を準備する。再 生液は水酸化カルシウムの場合, 水に難溶であるので, 水 酸化カルシウムを一定量科量し, $15 \mathrm{ml}$ の水で $50 \mathrm{ml}$ 栓 付遠心分離管に移し，その上に準備したアミン塩酸塩のべ ンゼン溶液 $15 \mathrm{ml}$ を加える。これを 15 分間振宣し, 2500 $\mathrm{rpm} 15$ 分間の遠心分離を行ない, 有機相中の遊離アミン 濃度を滴定により求めた。アンモニア水による再生では, 濃度既知のアンモニア水を用いて上記と同様の方法で処理 した。

\section{$4 \cdot 2$ 実験結果および考察}

第 7 図は水酸化カルシウムによるアミン塩酸塩の再生の 結果を水酸化カルシウムの濃度 (スラリ一状の均一液とし て計算した濃度 ) と再生したアミン濃度の関係として示し たものである。アミン塩酸塩と水酸化カルシウムは当量的 に反応して，アミン塩酸塩は遊離アミンとなることがわか る。水酸化カルシウムによるアミン塩酸塩の再生は反応的
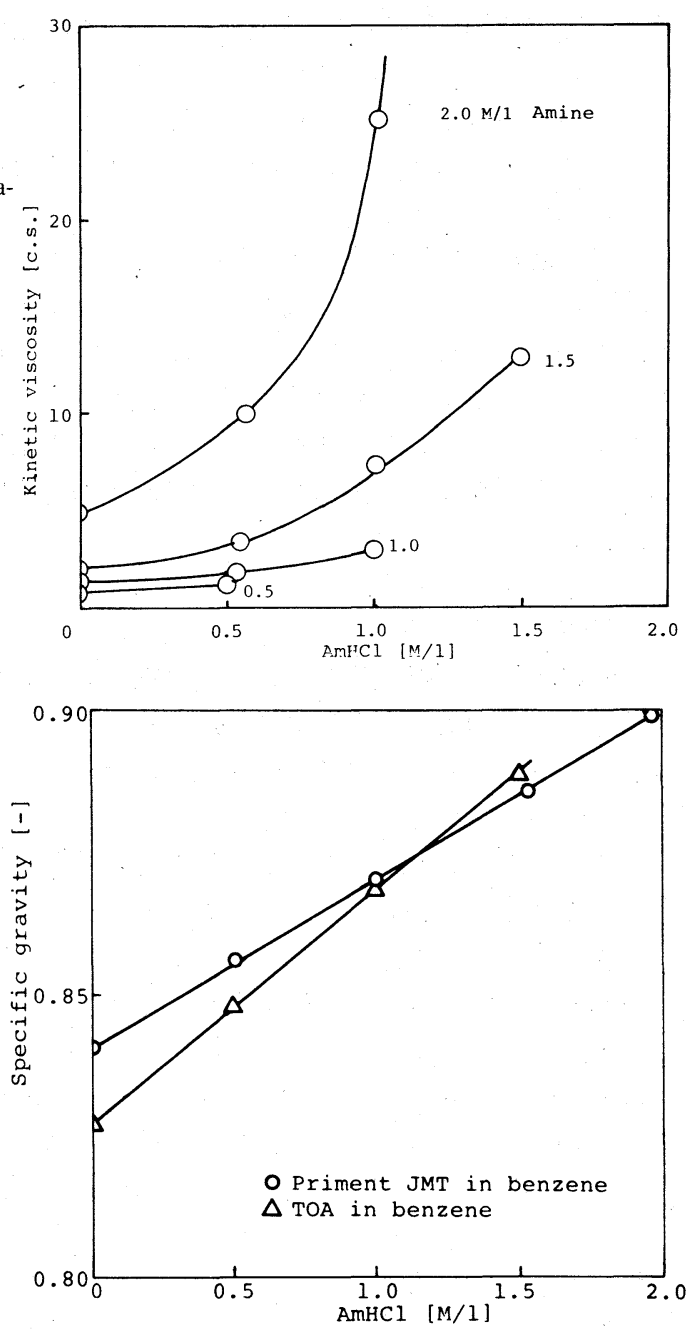

には容易であり，一段の接触により十分可能であると言え る。しかし, 再生処理後の液液界面にカルシウムの難溶性 塩と思われる膜状の物質が生じ, また重炭酸ナトリウム生 成に溶媒抽出法を適用する時には，有機相中に炭酸ガスが 飽和しているものと考えられるので溶解度の低い炭酸カル シウムが生じる可能性も考えられる。

第 8 図はアンモニア水濃度と再生したアミン濃度の関係 を示している。再生率 60 ～70\%までは水酸化カルシウム と同様に当量的に反応してアミン塩酸塩が再生されるが， それ以上では当量以上のアンモニア水を必要とする。第 4 表には,アミン塩酸塩とアンモニア水が当量の場合, アミ ソ塩酸塩とアンモ 相比を変化させた場合，2回接触した場合のそれぞれの再 生率を示している。これよりアミン塩酸塩濃度が増加する と, 当量のアンモニア水を用いる再生は難しくなり，一定 量のアンモニア水を用いるならば多回操作あるいは向流多 段操作が適当であることが認められる。アンモニア水によ る再生は水酸化カルシウムにくらべて再生効率は低下する が液液操作であるので, 操作は容易となる。しかし，式(14) に示されるようにアンモニアの回収工程を必要とし, 重炭 酸ナトリウム生成のプロセスの簡略化に対する寄与は少な くなる。 

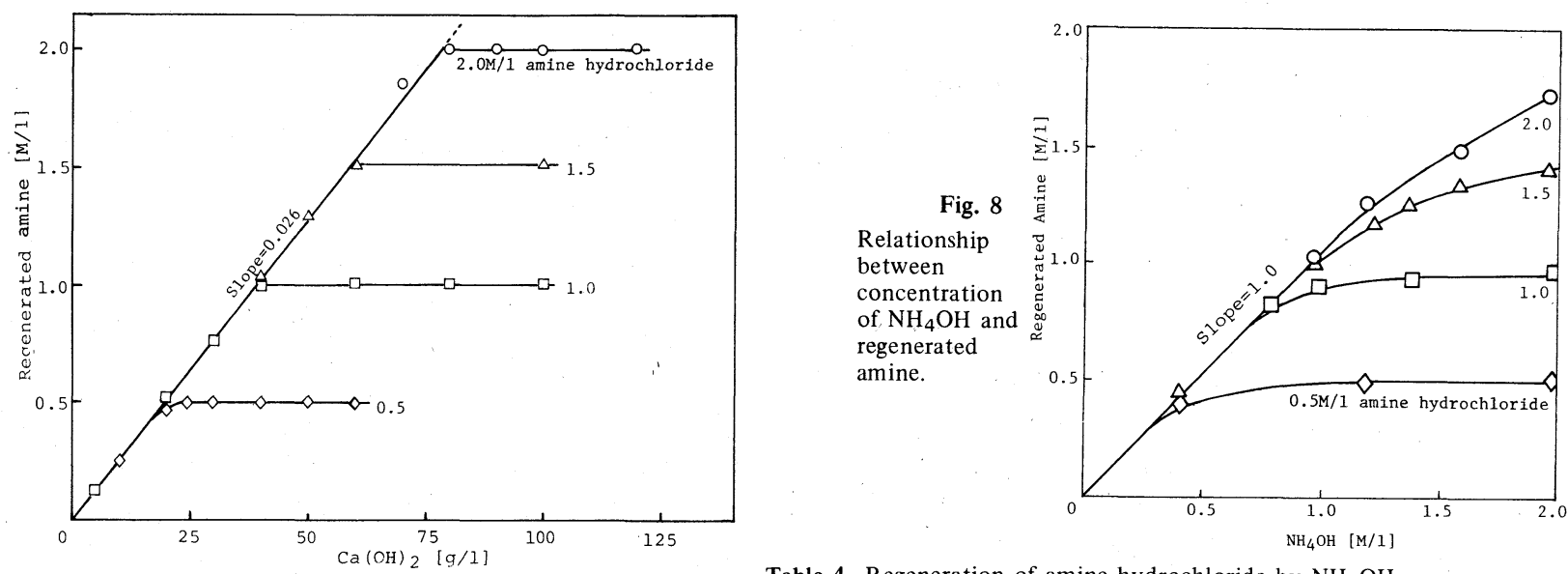

Table 4 Regeneration of amine hydrochloride by $\mathrm{NH}_{4} \mathrm{OH}$.

Fig. 7 Relationship between concentration of $\mathrm{Ca}(\mathrm{OH})_{2}$ and regenerated amine. Organic phase; Priment JMT in benzene.
5. 結 $\overline{\overline{⿳ 亠 二 口}}$

\begin{tabular}{c|c|c|c|c|c|c|c|c|r}
\hline & \multicolumn{3}{|c|}{ Equivalent contact } & \multicolumn{3}{c|}{ Change of phase ratio } & \multicolumn{3}{|c}{ Twice contact } \\
\hline AmHCl & 1.0 & 1.5 & 2.0 & 1.0 & 1.0 & 1.0 & 1.0 & 1.0 & 1.0 \\
$\mathrm{NH}_{4} \mathrm{OH}$ & 1.0 & 1.5 & 2.0 & 1.0 & 1.0 & 1.0 & 0.5 & 0.6 & 1.0 \\
$\mathrm{O}_{\text {A ratio }}$ & $1 / 1$ & $1 / 1$ & $1 / 1$ & $1 / 1$ & $1 / 2$ & $1 / 3$ & $1 / 1$ & $1 / 1$ & $1 / 1$ \\
\hline Regeneration: & 91.4 & 92.7 & 86.0 & 91.4 & 95.7 & 96.0 & 96.8 & 98.3 & 99.3 \\
\hline
\end{tabular}

アミン塩酸塩溶液の粘度は高く,実用には適さない。同様に

$1.5 \mathrm{~mol} / \mathrm{l}$ 以上の高いアミン濃度の使用も適切ではない。

アミン塩酸塩の分解再生は水酸化カルシウムおよびアン モニア水により比較的容易に行なうことができるが，重炭 酸ナトリウム生成工程の簡略化に対する寄与は水酸化カル シウムを用いる方が大である。

終りに，本実験を行なうに当り，協力された高木啓次君， 佐野まゆみ君 ( 当時本学学生 ) に感謝の意を表する。

文 献

1）功刀雅長 ·吉沢四郎 ·田村幹雄 : 工業化学概論上巻， 255 260, (1961), 丸善 (株)

2) F. Habashi : Principles of Extractive Metallurgy, 2, 335, (1970), Gordon and Breach Science Publishers

3) R. R. Grinstead: Solvent Extraction Chemistry, 426 $\sim 432$, (1967), North-Holland Publ ishing Company

4) C. F. Coleman, K. B. Brown, J: G. Moore and D. J. Crouse : Ind. Eng. Chem., 50, 1756 1762, (1958)

5) 化学便覧：571, 1003. (1966), 丸善 (株)

6) J. J. Bucher and R. M. Di amond : J. Phys. Chem., 69, 1565 1574, (1965)

7) H. Freiser and Q. Fernando : イオン平衡 (藤永・関戸共訳), 249 , (1970), 化学同人

8) 井上勝利·河野恵宣 - 中塩文行 ·坂井渡 : 化学工学, 38, 41 46, (1974)

\title{
On the Chemical and Physical Properties of High Molecular Alkylamine
}

\section{- Application of the solvent extraction to inorganic synthesis (1st Report) -}

\author{
by Junji SHIBATA ${ }^{1}$, Masaaki SAKAMOTO ${ }^{2}$, Jiro NAKANISHI ${ }^{2}$ and Sanji NISHIMURA ${ }^{3}$
}

The chemical and physical properties of high molecular alkylamine have been investigated to obtain the basic data on the production of sodium bicarbonate using the solvent extraction. The role of amines in the new process is to eliminate hydrochloric acid from the reaction system, which is byproduced simultaneously when sodium bicarbonate is formed from sodium chloride, carbon dioxide and water.

The base strength of amine, therefore, is the most important factor in applying the solvent extraction to the sodium bicarbonate production. The base strength of seven kinds of commercial liquid anion exchangers containing primary, secondary and tertiary amine has been compared.

Other properties, that is, the kinematic viscosity and specific gravity of amine and amine hydrochloride solutions, and the decomposition of amine hydrochloride have been also measured. These properties seem to be concemed with the phase separation and the regeneration of amine hydrochloride, respectively.
(1. Lecturer, Dr., Faculty of Engineering, Kansai Univ.
2. Faculty of engineering, Kansai Univ.)
(3. Prof., Dr., Faculty of Engineering, Kansai Univ. 